\title{
Aisthesis
}

Firenze University Press

www.fupress.com/aisthesis

OPEN ACCESS

Citation: V. Bartalesi (2021) Rethinking contact: the haptic in the viral era. Aisthesis 14(1):23-36. doi:10.36253/Aisthesis- 12481

Copyright: (c) 2021 V. Bartalesi. This is an open access, peer-reviewed article published by Firenze University Press (http://www.fupress.com/aisthesis) and distributed under the terms of the Creative Commons Attribution License, which permits unrestricted use, distribution, and reproduction in any medium, provided the original author and source are credited.

Data Availability Statement: All relevant data are within the paper and its Supporting Information files.

Competing Interests: The authors have declared that no competing interests exist.

\section{Rethinking contact: the haptic in the viral era}

\author{
VALENTINA BARTALESI \\ Università IULM, Milano \\ brtlsvalentina@gmail.com
}

\begin{abstract}
The current pandemic emergency due to Covid-19 has profoundly changed our sensory habits. What role can be assigned to a synaesthetic perceptive modality like the haptic in this no touching pandemic period (Žižek 2020)? This paper argues that the haptic specificity could go beyond the dialectic between touch and vision to focus on its phantasmagorical potentiality. In an attempt to grasp the relevance of this perceptive modality in the pandemic and post-pandemic scenario, this contribution will proceed in two directions. First, starting from an etymological premise and an iconographic excursus, it will highlight the motility and the potential in absentia as the proprium of haptic perception. Secondly, we will hypothesize the configuration of a synaesthetic and intermedial "haptic feeling" shaped by the accumulation of images of everyday pandemic life - phantasmata, eidolons and pictures - can disclose an infrasubtle space, substantially affective, which precedes and exceeds the contact itself.
\end{abstract}

Keywords: Haptic Perception, Digital Age, Covid-19, Sensory Studies, Iconography.

The state of emergency determined by the global spread of Covid-19 seems to have challenged the supremacy of «haptocentric intuitionism» (Derrida [2000]: 300).

In the ultra-visible era, dominated by the viral proliferation of screens, the syncretic flow of images and audio-visual contents (Montani [2020]: 17) consumed in a slippery mechanism of endless scrolls, and frequently experienced in virtual form, the sense of touch seems to suffer an additional offensive by the visual. Its denial acquires an extremely immunological and biopolitical quality in such circumstances, far from being confined to the centuries-old aesthetic querelle. The "invisible enemy", an epithet that has come into vogue in the pandemic syntax, imposes the configuration of a new gestural alphabet of the living body (Leib) for the survival of the individual and the community. Thus, the body must unlearn to touch itself, monitoring behaviours internalized since Prehistory (Rosen [2020]) and scrupulously supervising the work of the hands. Nevertheless, such peculiar species of literacy possesses a markedly techno-media character: the hand, an organ traditionally surged to tactile synecdo- 
che, no longer grasps the Other or grasps it only exceptionally (the limbs of the loved ones).

In a prosthetic relationship with screens and devices, the fingers brush against an impermanent body, virtualized into the two-dimensional limits of a display, and made paradoxically manipulable, even if substantially untouchable.

In front of the increasing predominance of the visual aptitude, both in private and public life in the viral era, professional and affective communications occour in Teams rooms and Zoom channels, in a strictly remote vision -, what role can be assigned to a border sense like the haptic?

In an attempt to gather the relevance of this perceptual modality in the pandemic and postpandemic scenario, this paper will proceed in three directions. First, starting from an etymological premise and an iconographic excursus, it will highlight as proprium of haptic perception its motility and potential in absentia, between tangibility and intangibility.

Second, it will hypothesize the configuration of a synaesthetic and intermedial "haptic feeling" shaped by the accumulation of images of the everyday pandemic - more specifically phantasmata, eidolons and pictures. Third and consequent to the other points, it will try to demonstrate how haptic feeling can disclose an infra-subtle space, essentially affective, which precedes and exceeds the contact itself.

\section{ETYMOLOGICAL PREMISE: HÁPTEIN, APTYCHUS, HAPTICS}

An etymological foreword about the multifaceted meanings of the term haptic could be helpful both to understand the specificity of this perceptive modality and propose a possible "pandemic iconography". In this regard, it is necessary to point out a few issues that make the investigation on the haptic remarkably layered.

They could be enucleated as follows: the polysemic nature of this noun/adjective, relevant to a transversal disciplinary spectrum; the polyse- mic configuration, in turn, of the sense of touch, often equalized with the haptic as if the latter represented its exotic counterpart; finally, the historically dominant tendency to absorb the haptic perception into the orbit of the visual, testified by the syncretic emblem of the touching eye and by the substantially panoptic orientation of German Kunstwissenschaft (Pinotti [2001]: 153-167; [2007]: 486; [2009]: 187-189). Lingering briefly on haptic etymology, therefore, allows us to identify those foundational characters for which the haptic becomes a synesthetic modality of perception, both familiar to the humanistic and technoinformatic investigation. The perspective that will be traced appears not necessarily organoleptic but rather «interoceptive» (Craig [2003]: 500).

The Greek etymon haptō, hence the term haptos (tangible, sensitive), the predicate háptein, and the adjective haptikós, from which derived, in turn, the French haptique, the German haptisch/ Haptik, and the English haptic, signifies, among other meanings, «to bind, join, knot, attach, knot for oneself, touch, adhere, take, embrace, have intimate relations, reach, strike (...)» (La Magna [1960]: 191, trad.). Reflecting on the etymon and not, as more frequently happens, on the expressions derived from it, usually translated as «able to come in contact with» (haptikós) (Bruno [2002]: 6) and «tighten, grasp, lace» (háptein) ${ }^{1}$, allows to highlight a fundamental quality of the haptic even in a psycho-physiological environment (Fulkerston [2020]). While the noun haphe describes the peculiar gesture of touching and squeezing, the qualities that combine the predicates mentioned above turn out to be motility (Active Touch) and the dynamism that precedes the experiences of contact (Gibson [1962]: 477478). Since its early enunciation, the haptic is the sense of a body tirelessly acting. It discloses an inframince space that corresponds to an equally interstitial distance, which includes the longing for possible contact. Concerning this etymologi-

1 “Haptics." Merriam-Webster.com Dictionary, MerriamWebster, https://www.merriam-webster.com/dictionary/ haptics. Accessed 10 Mar. 2021 


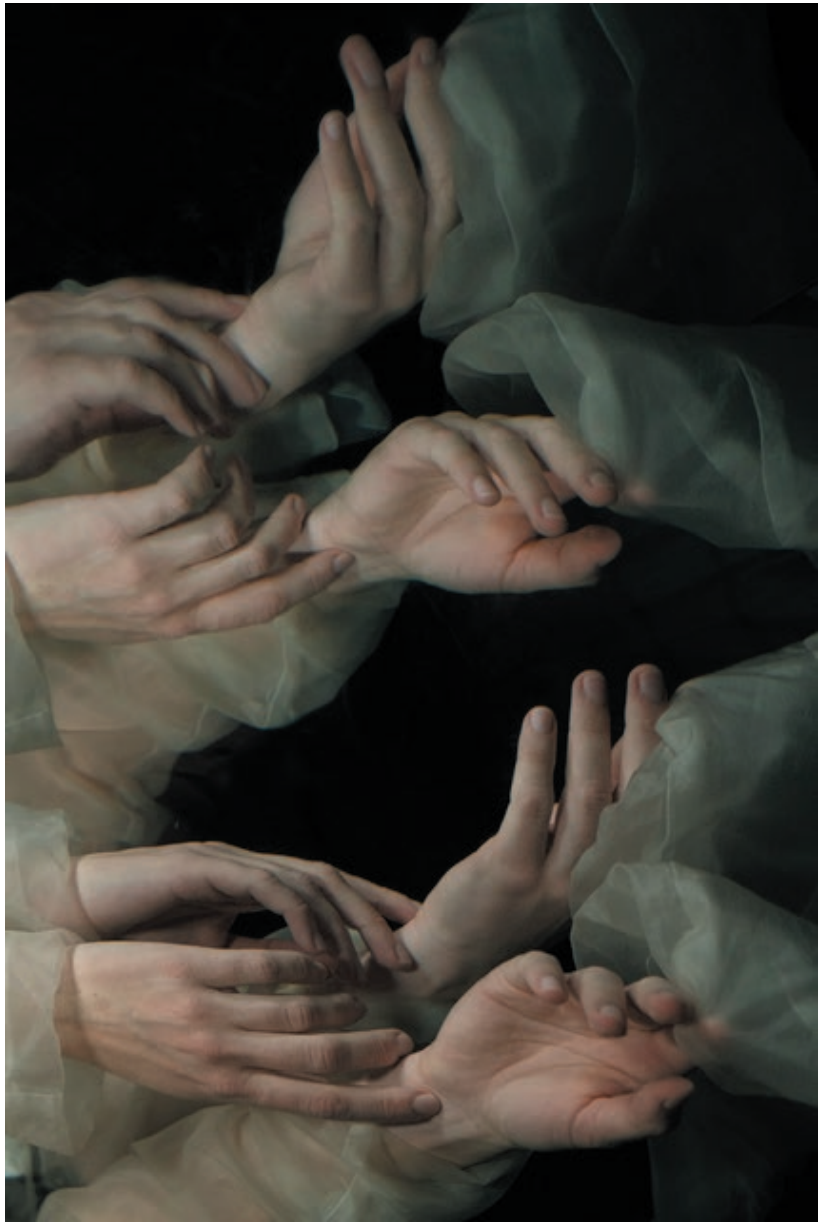

Figure 1: Henriette Sabroe Ebbesen, Genesis. Still 1, 2020. Digital print on textile, $787 / 10 \times 571 / 10$ in $200 \times 145 \mathrm{~cm}$, Editions $1-3$ of 3 .

cal variant, entered the lexicon of aesthetics and visual culture through the German studies of applied psychology of the late nineteenth century (Grunwald [2008]: 15-39), it seems appropriate to underline how the "haptic movement" includes affective-emotional elements related to the variant of the etymology haptō, in the biblical meaning of lighting and burning. It is in the wake of this suggestion that the motility of the haptic, as Giuliana Bruno said, com-moves, generating an emotional movement (Bruno [2002]: 6; [2014]: 19) grounded on «entropathy», the visceral resonance into the joints of the Other body (Nancy [2003]: 11, trad.) (Figure 1). However, a second and eccentric meaning of the term haptic exists and is pertinent to palaeontology. At this juncture, hap-

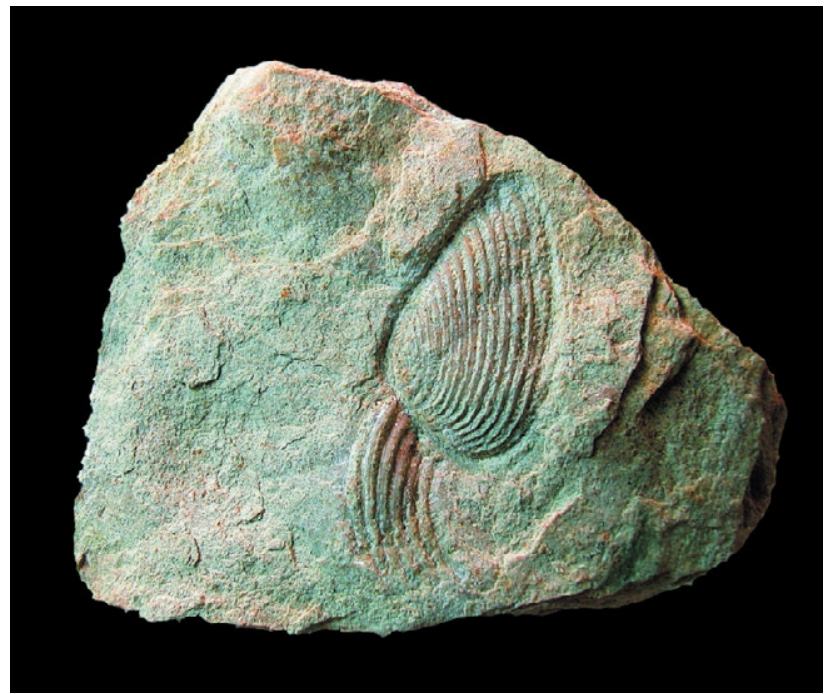

Figure 2: Aptico Monte Subasio, Courtesy Gruppo Umbro Mineralogico Paleontologico.

tic, a masculine noun derived from the scientific Latin aptychus (comp. of a- priv), and the Greek fold $(\pi \tau v \times \eta)^{2}$ is actualized in a fossil interface that connects - or should be said, ties? - the interior with the exterior (Figure 2). As a pelagic and liminal entity, it echoes the dual nature of a device that connects and protects, distinctive of the transhistorical principle of the arch-screen (Carbone [2018]: 4, trad.; [2016]: 168). Finally, a third variant of the term haptic derived from the feminine of the Greek word haptikós and the Neo-Latin word haptice, coined in 1685 by Isaac Barrow in Lectiones Mathematicae XXIII and translatable as «the science of touch».

Haptics, a word of cogent modernity, pertains to the science of touch in a techno-media perspective (Parisi [2018): passim). It denotes the tactile feedback (force feedback) generated by those devices that, by sending artificial stimuli to the proprioceptive and muscular level, simulate the sensation of actual contact (Grunwald [2008]: 355).

According to the etymological discussion, it can therefore be said that the haptic, far from endorsing a synonymous relationship with the

\footnotetext{
${ }^{2}$ Ibidem.
} 
tactile, focuses on motility - to borrow from Micla Petrelli, the haptic collects the "ulteriority» of the sense of touch, representing «its extension, its substrate» (Petrelli [2015]: 4, trad.). Such motility results interceptive - «the haptic, (...) enacts the feeling or rather is itself, in fruition, feeling» (Mazzocut-Mis [2001]: 139, trad.) - as well as exteroceptive, aimed at grasping the «noetic dimension» rather than the mere "passionate contact with the projecting body of things» (Petrelli [2015]: 9, trad.).

The interstitial space of the haptic, the prehensility that it implies and of which it becomes a supporter, realizes itself in a non-material «grasp» (Franzini [2017]: 85-86, trad). More precisely, it results in an analytical and phantasmatic grasping. This fleeting space promises access to knowledge that is «obscure» and denied to a «regulated and categorized vision» (ivi: 86).

\section{PANDEMIC ICONOGRAPHY: CONTACT BETWEEN ABSENCE AND DESIRE}

In order to recognize an iconographic exemplum that reveals haptic etymological polysemy in the pandemic scenario, a cinematic sequence frequently mentioned (Gallese [2015]: 209-2013; Barker [2009]: 28-29), paradigmatic for the detachment between disembodied touching and affection, results in the prologue of Persona (1966) by Ingmar Bergman (Figure 3). In the roughness of black and white, what the moving images vividly render coincides with the phenomenon of

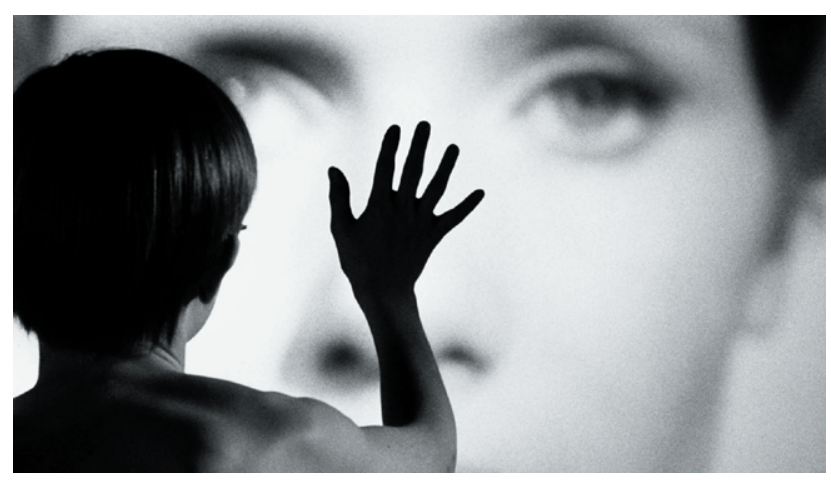

Figure 3: I. Bergman, Persona, 1966. splitting between display and screen already highlighted by Wanda Strauven, although in a different context ([2018]: 70). This rupture, whose consequences have dramatically reemerged in lockdown everyday life, exhibits the paradox in which the object of touching coincides with the screen surface and not with the images flowing through the display (ibidem). Furthermore, the camera movement placed us in the frustrating condition of the anonymous young boy in Persona, concentrating on caressing the screen images of two female figures with his fingers. If this sequence emphasizes the opacity of a medium (the screen) that essentially inhibits the possibility of coming into contact with the Other, thus risking to legitimize technophobic readings already questioned in recent times (Carbone [2020]), turning the attention to the appearance (phainesthai) of the image could be helpful to reconfigure the notion of contact in a pandemic and even post-pandemic key. In this sense, a sequence that proves the morphology of a hybrid contact is that of the replicant-hologram relationship in Denis Villeneuve's Blade Runner 2049 (2017) (Figure 4). Indeed, this scene shows the organic and inorganic intertwine that Mario Perniola defined, just starting from the Homeric etymology of ápto, «a state in which things are interpenetrated but still preserve their nature» (Perniola [1994]: 75). In a dystopian, even if not pandemic horizon, the feature film deploys an evocative register of intermedial images, exhibiting phantasmata, eidolons and pictures, that saturate the polluted atmosphere of a post-human world, in which Wearable Technologies (WT) have conquered the status of ordinary bodily prostheses. What seems pivotal here for the

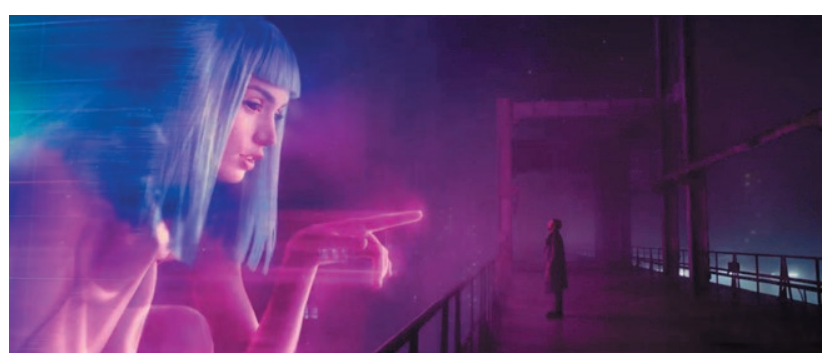

Figure 4: Frame from Blade Runner 2049 by D. Villeneuve, 2017. 


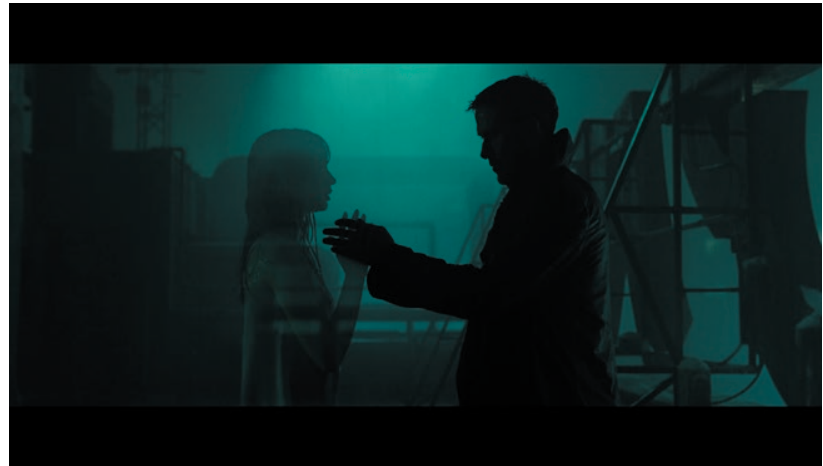

Figure 5: Frame from Blade Runner 2049 by D. Villeneuve, 2017.

pandemic notion of haptic concerns the gap that such «an-iconic» experiences (Pinotti [2018b]: 233, trad.) trigger in the notion of proximity.

In the wake of the considerations elaborated by Rabbito [2020] and Eugeni [2018], what emerges from the ambiguous relationship between the replicant K (Ryan Gosling) and the holographic interface Joi (Ana de Armas) is precisely the discrepancy of touching in a perspective complementary to the Bergmanian one. Employing a device perhaps unconsciously yearned for during the pandemic isolation, namely an emanator that allows the hologram to move freely, Joi discloses herself as a realistic weave of lights and not a Körper of skin and flesh. For those physiological and technical reasons, the emotional affair that the characters entertain is hinged on the intangible (Figure 5).

According to Baudrillard's interpretation of trompe-l'oeil, a simulacral entity and technique that solicits «tactile fantasy» and «tactile hyper presence of things, as if one could hold them in one's hand» (Baudrillard [1979]: 63), without however imposing itself as a surplus of the real, the fictitious three-dimensionality of hologram opens a crisis within the reality of touching. More precisely, touching, here understood in its extreme haptic motility, coincides with the interspace that exists between the "body without substance" of the hologram and the one of the replicants in the act of touching (Figure 6). Therefore, the Husserlian «double sensation» (Doppelempfindung) (Boccali [2019]: 111, trad.) falls between sentient

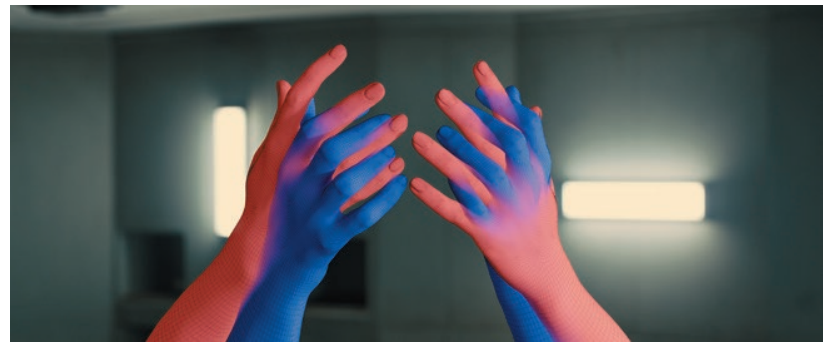

Figure 6: Digital overlay reconstruction of Joi (Ana de Armas) e Mariette (Mackenzie Davis), in D. Villeneuve, Blade Runner 2049, 2017.

and touching bodies since Joi turns out to be programmed as an entity deprived of touching reversibility. Thus, the contact is realized in a simulation internalized by both characters, in which their images overlap and superimpose. However, they do not and could never come to touch each other effectively. This regime of intangibility leads them into a state of suspension, not dissimilar to the polarization between the body-ego and the digitized Other, which has become the primary relational mode of the viral era.

To circumvent the barrier of screen opacity, what the syncretic relation of Blade Runner 2049 makes manifest, thanks to the avant-gardist coefficient of special effects, concerns the «spacing" (Derrida [2000]: 35) that the experience of the haptic discloses within the intangible. Hence, in the intangible, immunological paradigm of the pandemic and structural feature of the hologram, the motility of the haptic can reach its highest interoceptive coefficient and, consequently, its limit. In Derrida's words, "what is it to touch one's own limit thus? It is also not to touch, not to touch oneself enough, to touch oneself too much: impossible sublimity of tact, the diabolical machination of love when it dictates infinite renunciation» (ivi: 111, emphasis mine). According to Derrida, such sublimity implies an «interruption» in the contact, a «syncope» close to the one that shapes Nancy's thought on touch (ibidem). As a counterpoint to the interruption stands out the infinite renunciation, the retreat of the object of desire, Barthesianly "always absent» (Barthes [1977]: 15). Locating the fascination at the 
«extreme of detachment» (ivi: 72), Barthes conceived absence as a physical entity to be manipulated (ivi: 16), in the extreme attempt to hold back, to «delay as long as possible the moment when the other might topple sharply from absence into death» (ibidem).

\section{BEYOND «TOUCH-PHOBIA» AS A CRITICAL PARADIGM}

Inscribing the specificity of the haptic in the interruption, in the movement in potentia, allows us to evaluate what Didi-Huberman defined as "phobia of touch», referring to the art-historical field (Didi-Huberman [2008]: 87, trad.). Even then, Didi-Huberman prophetically adopted viralsounding terms such as «anthropological paradigm» of «transmission» (ivi: 48) and «contagious magic» (ivi: 69). The author, inserting himself in the centuries-old aesthetical debate on the competition between touch and sight, associated this phobia to the modern (basically theoretical) rejection of the excessively carnal and inconveniently mimetic morphogenesis of particular artistic techniques (namely, those obtained by imprint).

Between the Paragone delle Arti and the Greenbergian media specificity, the junction at which this excess finally overcoming the ideological impasse of a téchne regarded as degrading is located in the last quarter of the eighteenth century. As pointed out by Elio Franzini, Herder's merit was to have systematized the relationship between touch and sculpture on the heels of previous treatises, which from Condillac to Burke recognized in touch a subordinate sense endowed with an analytically obscure quality (Franzini [2013]: 185, trad.). However, it is striking to note how Herder, who recognized sight as a sense dependent on touching - «We believe we see something when in fact we touch it and where only touch is appropriate» (Herder [1778]: 38) - already supposes what Andrea Pinotti has emblematically called «a Herderian uncertainty» (Pinotti [2009]: 181, trad.). A symptom of this aesthetic short-circuit that disorients the German philosopher's system, based

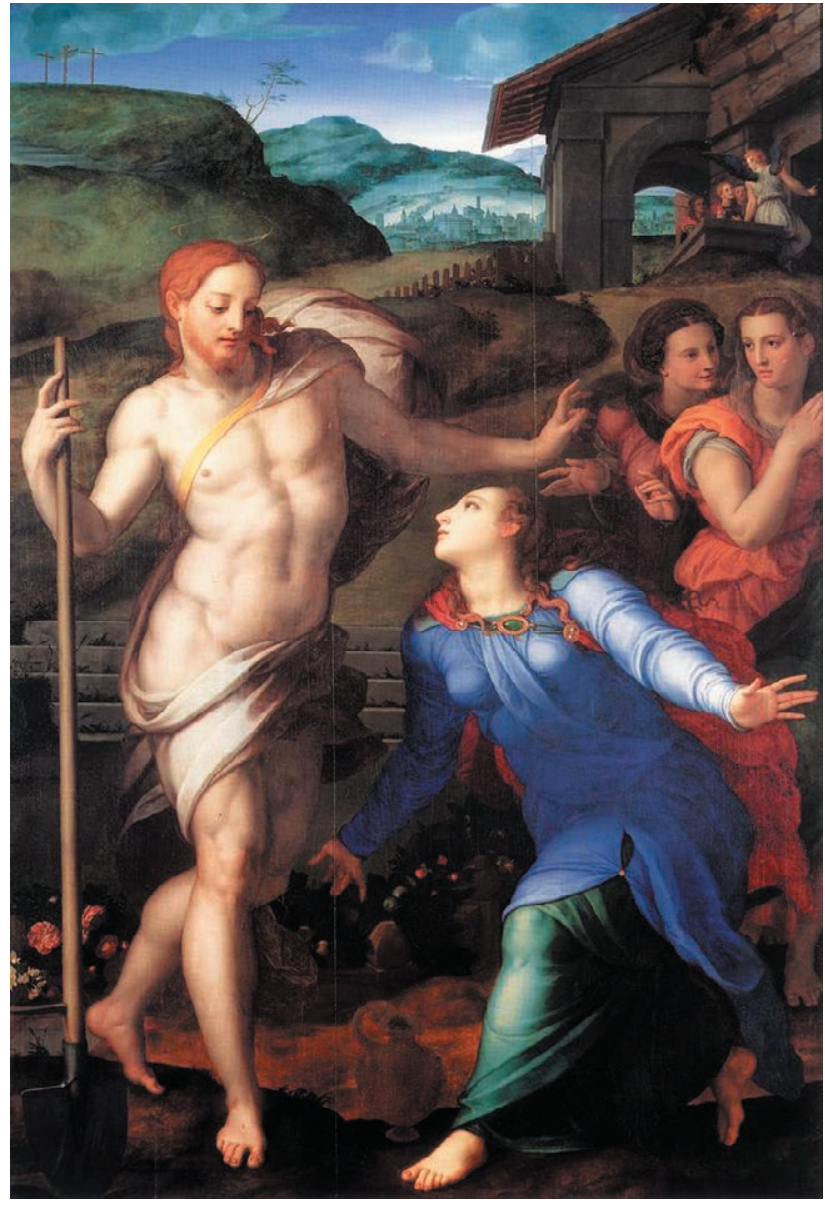

Figure 7: Agnolo Bronzino, Noli Me Tangere, 1561. Oil on poplar wood, 291 x $195 \mathrm{~cm}$. Paris, Museo del Louvre.

on the dialectic between touch and sight, distinctly arises when Herder empathizes with that sculptor who cannot touch his creation, «not even in a dream». As Pinotti argues, this excerpt establishes a crucial turning point since Herder transposes the gesture of touching into an imaginative horizon, alluding to the possibility "of touching in a dream, of a virtual, imagined touch» (ibidem).

Considering the breach that deepens the pandemic interdiction of touching and touching each other, it reveals a perceptological horizon grounded on the interstice between tangible and intangible. It falls on the Noli me tangere iconography to intensely reify that invisible space in which haptic feeling is positioned (Figure 7). 


\section{NOLI ME TANGERE, MẼ MOU HAPTOU: THE INFRAMINCE SPACE OF THE HAPTIC}

It should not be astonishing that, introducing the pamphlet dramatically entitled Pandemic! the Slovenian philosopher Slavoj Žižek turns to the ancient Christian expression of «Noli me tangere» (Žižek [2020]: 1). The choice of biblical iconography, indeed, not only emphasizes the individual and collective veto imposed by the spread of the pandemic but exceedingly highlights the penetrating quality of «a deep look», a vehicle of intimacy even more intense than actual contact (ivi: 2). According to Jean-Luc Nancy, as compared to other idiomatic expressions, the Noli me tangere presupposes, on the one hand, the existence of a situation of potential hazard (Nancy [2008]: 13) - the anguish of a contagion that one can unconsciously activate or suffer. But, on the other hand, it unseals the "space without dimension", to such a rarefied point that it condenses within the «line that separates the touching from the touched and so the touching itself» (ibidem). At least, the materialization of this «scarto partes extra partes» (Caldarone [2011]: 50) allows us to make two observations tightly interrelated.

First, a linguistic reflection rich in consequences on the theoretical level. Namely, the fact that Nancy, digging up into the Greek syntagma $m \bar{e}$ mou haptou, goes back to a privative meaning of the predicate háptein translatable as «to hold back, to stop» (Nancy, [2008], 15). In this sense, the author claims that in John's Gospel account, to Mary of Magdala is denied even the possibility of touch, since the Saviour's body has already risen to a body that is no longer tangible, the «appearing of an appeared and disappeared [un apparu et disparu]» (ivi: 28). Beyond the theological and teleological horizon of salvation, it seems at least peculiar to observe how the biblical narration outlines a phantasmatic presence not dissimilar, in its transient and untouchable being, from the functioning of the holographic image mentioned above (ibidem).

Second, it is in the absence that touching is accomplished, in letting go, since Magdalene is inhibited even from the desire to touch (hàptein) (ivi: 37). This specific point is based on the comparison with the evangelical pendant of the Incredulity of Saint Thomas (Most [2005]: 41). Instead, it aims to crystallize in the image the substantial motility of the haptic, exemplified by the distance existing between the hands and the outstretching of Mary Magdalene's whole body.

Here, a hiatus opens up concerning the surreptitiously «vulva-like» dynamism with which the finger of Thomas, the incredulous apostle, penetrates the plague on Christ's ribs (Most [2005]: 164): the blasphemous euphoria to brush and being brushed by the heavenly body culminates in the satisfaction of a digital desire. At that time, the hand, à la Deleuze, «is reduced to a finger» ([1981]: 104) or to a supervising pupil. Nevertheless, breaking the space of distance - the

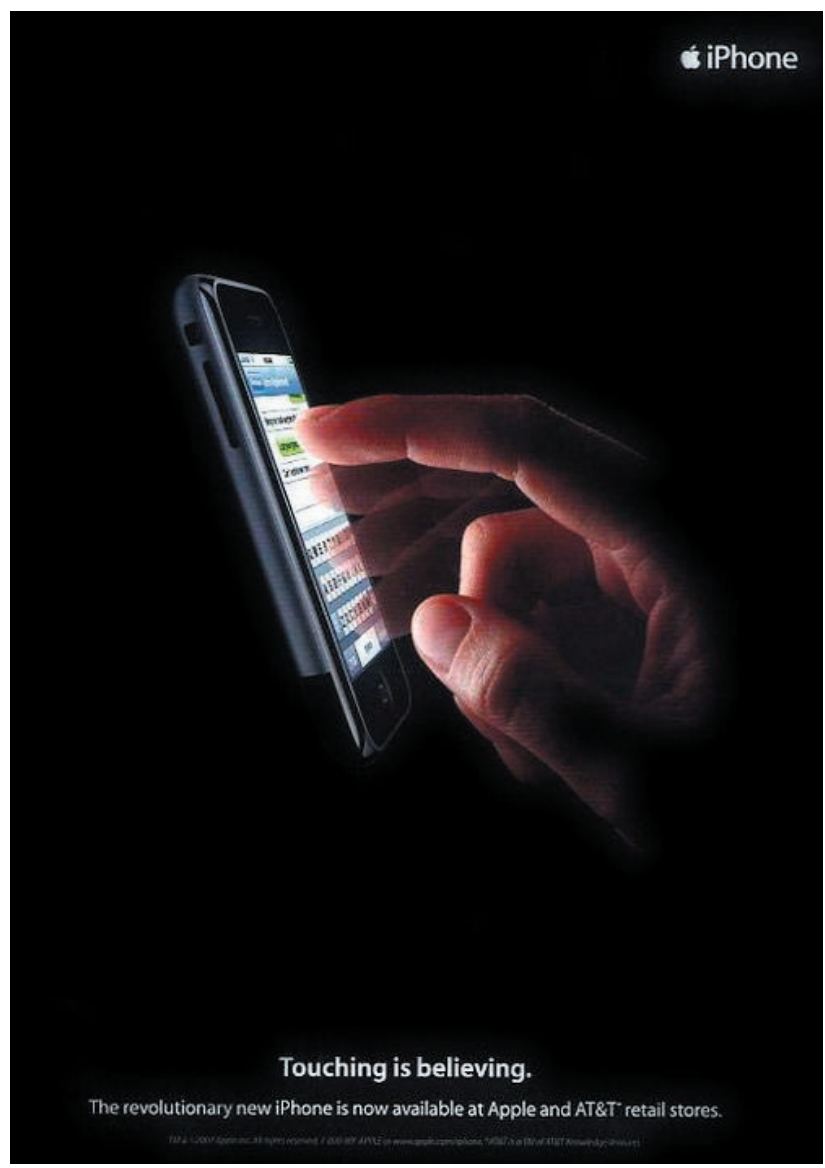

Figure 8: iPhone Apple advertisement, Touching is believing, 2007. 
measures of containment and security -, equally nurtures a horizon of intangibility if one recollects how the New Testament synopsis ultimately does not contemplate any form of palpation (Most [2005]: 21, 55, 57). This ambiguous dimension of the contactus is reflected unintentionally in an advertisement launched by Apple in 2007. As will be illustrated below, the occasion was technically touching: the release of the first iPhone.

\section{THE INCREDULITY OF THOMAS AND THE LIMITS OF «FINGERBOMBING»}

At the mercy of a bodiless hand, an iPhone twinkles hanging in the darkness, phantasmagorical in its being "chronophotographed" while typing (Figure 8). A la Barthes, this is the "great tactile phase of discovery» (Barthes [1957]: 90), not automotive, but equally mechanical, haptic in both the polished communication that the device conveys (Han [2015]: 2-3) - the display exhibits a screenshot of the Whatsapp messaging app - and in its irresistibly seductive materiality (ivi: passim). This dual aptitude of the device acquires further importance if we consider how between the first and the fourth quarter of 2020, in two apical moments of the pandemic emergency, the American multinational sold over 19 thousand units of iPhone 11 and 79 thousand iPhone 12 (Stamford [2021]), confirming the ubiquity of touch screens as a means of entertainment and communication. Omnipresence, however, shared with other brands (Samsung and Xiaomi are around 62 thousand and 43 thousand), reached at the same time when the avant-gardist technologies of Predictive Touch were being tested, aimed to substitute the actual touch with a Touchless system of artificial intelligence and eye-tracking (Scialom [2020]).

Given this scenario, recent studies show how the automatism of typing practised on the screen or the trackpad has helped change the habits about purchasing goods on the network (Mason [2020]). At the same time, it has soothed the feeling of physical and social isolation (in the «together apart» logic), exploiting with unprecedented intensity the chance of staying globally in touch thanks to social networks (Gabbiadini et al. [2020]). Nevertheless, the providential role recognized to these devices in the pandemic everyday life seems insufficient to fill the margin of intangibility materialized by the screen, an alleged technophilic analogue of the resurrected body. Although Apple's advertising recited the statement «touching is believing» (emphasis mine), counterfeiting the evangelical expression «seeing is believing» (Most [2005]: 47), what the digital relations in the viral age have invoked coincides with a peculiar experience of «ingression» (Böhme [2001]: 83, trad.), generated within a dimensionless emotional edge that intertwines devices and private spaces. The haptic feeling is not absolutized in the compulsion of an automatic tactility but extends itself to the visual and auditory area, taking advantage of the corresponding imaginary and mnestic potential.

To say, in other words, that the belligerent «fingerbombing» (Parisi [2008]: passim) cleverly dissimulated by the auratic appearance of the device, Benjaminian phantasmagoric in soliciting the incautious consumer to «its manipulations, enjoying its estrangement from self and others» (Pinotti [2018a]: 56), would coincide with the visible gesture of the experience of contact, without equally exhausting it. The instantaneous appropriation of what lies beyond the screen, as Cupertino's Incredulity persuades one to believe, exploits that desire of the masses that Benjamin already called «ardent» to "bring oneself closer» to things, to tactilely extinguish distances (Benjamin-Archiv

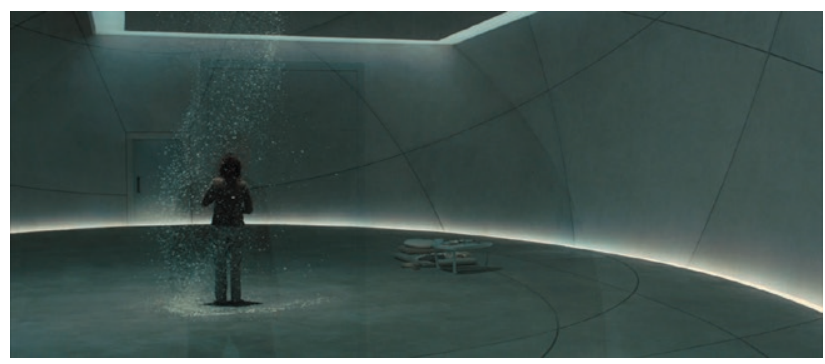

Figure 9: Creation of a Graft from Blade Runner 2049 by D. Villeneuve, 2017. 
Ms 386; Pinotti [2012]: 67), arousing the longing of the so-called «transparency society» (Han [2012]: passim).

This passage appears to herald suggestions even for the present pandemic. Since, as Han argues adopting an unconventional position, the implosion of the imagosphere would have paradoxically instigated a tactile modus of being in the real (Han [2012]: 13) grounded on the neutralization of the shock moments, in which Benjamin glimpsed the modernity of tactile media.

For these reasons, the dyad of elements that will be taken as paradigmatic for theoretical analysis avoids the immediacy of touching. Conversely, it will include the fleeting interlude the inframince space that separates replicant and hologram, the yearning that hinders and fills the non-touching of Mary of Magdala - and the faculty imagination to outline an image theory of pandemic "haptic feeling".

\section{HAPTIC FEELING: FOR A PHANTASMATIC THEORY OF IMAGES}

In order to introduce the theoretical section of the contribution, it will be necessary to dwell a few more moments on the imagosphere exhibited in Blade Runner 2049. As mentioned, what is striking about the feature film, along with the medial milieu it inaugurated, results in the heterogeneity of iconic experiences that it spread out: in particular, three-dimensional grafts and eidolons, pictures projected onto screens of varying sizes, holographic simulacra (Figure 9). If even the sensitive appearances of phantasmata had been included among these, Blade Runner 2049 might return an iconographical scenario, albeit technologically less advanced, of the fruition of body images in the viral era according to the triple activity of reproductive, productive and interactive imagination (Montani [2014]: 12).

Starting from the etymological and physiological motility of the haptic, here we propose the neological locution of haptic feeling, in which the feeling of one's own body - the most appro- priate verbal equivalent appears the English to feel/«feeling-with» (Paterson [2007]: 147) — is consumed in a perceptual synaesthetic horizon. In this way, haptic feeling results strictly based on the «indirect co-presence» of the percipient subject and perceived object, on which we will return shortly (Böhme [2001]: 118, 120, trad.). Nevertheless, what sort of haptic feeling did the pandemic state of emergency help shape?

Recalling the Benjaminian model of innervation, the training to telepresence that healthcare limitations have imposed and accelerated, in which social contact coincides with the editing in absentia of audiovisual materials seems to prevent the outline of an ileomorphic ontology, Cartesianally anchored on res extensa. Instead, even if the digital world is endowed with its peculiar materiality made of pixels and supports, what the haptic feeling seems to favour is the breaching of a state of suspension in which the "appearancesphantasmata» (Boffi [2009]: 296, trad.) exhibits their quality of affectio-onis, almost sensitive things that impress. The cruxes stressed by this formulation are several and need to be methodically explained in order.

First of all, the non-contact aptitude intensified by social and health restrictions raises the question, not unimpressive, of how to conceive a perception experienced in absence. The configuring of such a collective habitus is to be found since the 2010s, and even earlier in terms of critical discussion, according to Derrida ([2000]: 300301) and Žižek [1997] as a result of technological improvement, globalization and hyper connection. In the absence, is meant, of the Other's body, which has been textured within a binary code or introjected into a phantasmal image during the past year. Assuming the theoretical position elaborated by Böhme in the early 2000s, we will be inclined to identify a strategy that essentially extends the phenomenology of presence, referable to what he defines as «indirect co-presence» (Böhme [2001]: 119-120, trad.).

To illustrate this species of being and giving oneself, which Böhme considers within the framework of the generation (and fruition) of 
atmospheres, he invokes a series of circumstances in which the noetic moment of proximity results radically reconsidered. The sidereal image whereby a star is perceived as near, even though it is light-years away, is echoed in the feeling of proximity - a prophetic observation, compared to the everyday life of the viral era - that the percipient feels when hearing a telephone voice, however distant it may be (ibidem). This reconfiguration, however, does not seem exempt from the dynamics of reversibility. Thus, carrying over the astral metaphor related to the intromission theory, it is the emanation of rays projected by «a real body, which was there», as Barthes said, that touches us, just like the "deferred rays of a star» (Barthes [1980]: 80-81). In a theoretical scenario already critically outlined (Ghilardi [2011]: 33-34; Paterson [2007]: 147-172), present-day pandemic seems to foster a way of encounter that exceeds material contactus: but rather it concerns the phantas$m a$ image, an entity bound to inflame the "emotional-affective dimension» of the mind (Bianca [2017]: 19) in a cognitively multimodal way.

In the pandemic present, this happened within that state of suspension often identified with the notion of epochè (Mitchell [2020]; Žižek [2020]: 98). Thus, on the one hand, the suspension is configured as a punctiform counterpoint to the space of the haptic, which sometimes constitutes «the only access to otherness, a way to feel close to all the isolated people on Earth», as Catherine Malabou noted on March 23, 2020 (Malabou [2020]). Nevertheless, on the other hand, it represents the conditio sine qua non of the vis imaginativa. As asserted by Foucault and Žižek in different times, if imagining is not positioned in an unreality regime à la Sartre, practising imaginative activity, which precedes and is fulfilled in the creation of an image (Boffi [2009]: 399-404, trad.), corresponds to «regaining that original movement of our existences», which implies a co-inhabitation of the same world «as entirely new in my presence» (ivi: 402). It is «the subject's phantasmatic frame» that allows the subject to survive the «overproximity» (Žižek: [1997]: 67) that shapes the encounter with one's neighbour, declaring non- contact as the third foundational element of emotional discourse.

Concerning the Foucaultian destructive transition from imagination to image, the enforced remote communication have profoundly connected these categories. Furthermore, the pervasive employment of social networks and digital technologies as a pandemic pharmakon has contributed to model subjective and ephemeral worlds, in which the motility of the haptic appears technically shaped by media forms that generate it. As will be seen shortly, from phantasmata, we will then move on to simulacra.

\section{HAPTIC SOUNDS: VOICES}

Focusing on the synaesthetic quality of haptic hearing allows us to include a metaphorically and physically touching interlocutor frequently disregarded: the voice. In the Covid-19 era, the voice has acquired a renewed intermedial centrality, both when it resonates without an image or contributes to shaping a particular atmosphere, amplifying itself through the screen's interface. Consider, for example, the disembodied and alluring telephone voice of Samantha, artificial intelligence from the not-so-distant futuristic world of Her (2013) by Spike Jonze.

In this sense, the interdiction of physical contact has solicited the reevaluation of the similarity between voice and indexical trace, gathered in the Derridean locution of "double imprint». Thus, it is the echo phenomenon that presides over that sympathetic and synaesthetic resonance (along with sight), which makes such perceptual forms «modalities of haptical approach or appropriation»(Derrida [2000]: 148, emphasis mine). A particular passage of the French philosopher appears, a fortiori, rich in enlightening suggestions about the haptic and stratified sound quality. The author follows the vicissitudes of a couple of lovers separated for life. Unfamiliar with but not deprived of a potential ecstatic condition, they avoid the "tragedy» of detachment, caring «the spectral phantasm of ecstatic pleasure» and nour- 
ishing of «the telephonic memory of a touching» (Derrida [2000]: 113). As Derrida concisely notes, a "phantasm gratifies them» (ibidem, emphasis mine).

In the collective physical and social isolation due to the pandemic in which, as we have tried to argue, the encounter with the Other takes place in the hypertextual forms of narration through images, voice acquires the role of a haptic interface (aptychus) that connects heterogeneous systems. In other words, it represents a medium not only between the iconosphere and the real but also between Reality and the real, according to the Lacanian binomial recalled by Žižek ([1997]: 66). Furthermore, because the voice itself is configured as a particularly complex haptic device, this medial capability can arise. In this sense, the voice holds respectively: its indexical morphogenesis as a result of an intracorporeal phonic itinerary; its participation not in the eidetic faculty of the phantasma, but rather in the exosomatic and touching faculty of Lucretian simulacrum, modelled on the Epicurean concept of eidola.

The current pandemic situation seems to have reconfigured this Lucretian notion, exploiting the undulatory nature of a sound that does not disperse in the distance and that, also by its motility, allows reaching immaterial emotional proximity. Hence, the simulacral image offers suggestive medial perspectives for the post-pandemic future. Specifically, the "rerum simulacra», compared by Lucretius to very lightweight images that fluctuate swiftly in the ether as sort of «quasi membranae vel cortex» (Fellin [2013]: 232-233), seem to represent the genealogical forerunner of a technology capable of reformulating the connection between presence and contact: that is, holograms.

\section{CONCLUSIONS AND POSSIBLE MEDIAL FUTURES}

To conclude, the consequences of the state of pandemic emergency have elicited an unexpected acceleration in the configuration of the media landscape, actively contributing to the rewriting of subjective and public cartographies. Among the "re-emergence" and innovations that have occurred, we could include: the awareness of the potentialities inherent in screens (Carbone [2020]); the predominant role of material engagement in social media (Montani [2020]: 25-26); the cross-sectional diffusion of Virtual Reality devices, variously employed in medical/healthcare field (Singh et al. [2020]), gymnastics/ludic environment, and as a substitute for tourism-related activities (Sarkady et al. [2021]); the proliferation of applications that exploit Augmented Reality (AR) hybrid systems - from Google Art \& Culture to the Acute Art project; the proliferation of podcasts entirely based on the voice and sound element - culminating in the launch of the Clubhouse platform produced by Alpha Exploration \& Co in January 2020.

However, the most promising horizon for the haptic co-presence advocated by the present contribution coincides with what Simone Arcagni defined since 2018 as «the era of holograms (...) those three-dimensional images that float in the air (...), visible from every point of view without the use of special glasses, creating the illusion that the person or object we are looking at is in the same room as us» (Arcagni [2018]: 219, trad.). The futuristic dream of proximity in the distance, of a nonphantasmal bodily being, longed for by sci-fi cinematography in the past decade, is being designed with Ikin's $R Y Z$ hologram device. Overcoming the limits of invasiveness and compatibility frequently attributed to the use of VR visors, this interface, according to its creators, would allow enjoying brilliant holograms simply by employing the smartphone, through a system of Full Touch Interactivity probably supported by Ultraleap Haptics.

While it may be premature to formulate reflections about this rising technology, the suspicion that an element of intangibility subsists, even in the front of realistic tactile feedback, endures (Figure 10). In other words, this would not be sufficient to violate that condition of intangibility that constitutes «the ghostly revenant (phantasma), at the heart of (self-)feeling» (Derrida [2000]: 35). 


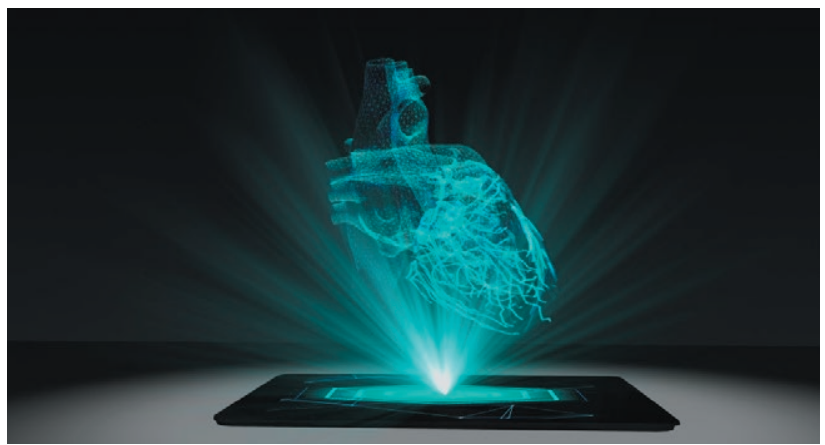

Figure 10: Hologram prototype generated by Ikin’s RYZ.

\section{BIBLIOGRAPHY}

Arcagni, S., 2018: Locchio della macchina, Einaudi, Torino (e-book).

Barker, J.M., 2009: The tactile eye: Touch and the Cinematic Experience, University of California Press, Berkeley.

Barthes, R., 1957: Mythologies, transl. by A. Lavers, The Noonday Press, New York, 1972.

Barthes, R., 1977: A Lover's Discourse: Fragments, transl. by R. Howard, Hill and Wang, New York, 1978.

Barthes, R., 1980: Camera Lucida. Reflections on Photography, transl. by R. Howard, Hill and Wang, New York, 1981.

Baudrillard, J., 1979: Seduction, transl. by B. Singer, CTheory Books, New York, 2001.

Benjamin, W., 1936-1940: Benjamin-Archiv Ms 386, Paralipomena e materiale vario per la terza stesura del saggio L'opera d'arte nell'epoca della sua riproducibilità tecnica, in Aura $e$ Choc. Saggi sulla teoria dei media, a cura di A. Pinotti, A. Somaini, Einaudi, Torino, 2012, p. 67.

Bianca, M.L., 2017: The Nomiotic-Wave Theory of Mind and Inherent Logic, Cambridge Scholar Publishing, Cambridge.

Boccali, R. 2019: Toccare l'alterità: fenomenologia e percezione tattile, "Alla fontana di Silöe: studi in onore di Carlo Vinti", Orthotes Editrice, 2019, pp. 109-118.

Boffi, G., et al, 2009: Percorsi di estetica. Arte, Bellezza, Immaginazione, Morcelliana, Brescia, 2012.
Böhme, G., 2001: Atmosfere, estasi, messe in scena. Lestetica come teoria generale della percezione, transl. by et eds T. Griffero, Christian Marinotti edizioni, Milano, 2010.

Bruno, G., 2002: Atlas of Emotions. Journeys in Art, Architecture, and Film, Verso, New York.

Bruno, G., 2014: Surface. Matters of Aisthetics, Materiality, and Media, University of Chicago Press, Chicago : London.

Caldarone, R., 2011: Eros e techne. "Nella mano che trattiene una mano assente", "B@BELONLINE.PRINT", I, 10-11, pp. 49-57.

Carbone, M., 2018: Dei poteri dellarchi-schermo e dell'ideologia della Trasparenza 2.0, "Between", VIII, n. 16, pp. 1-20.

Carbone, M., 2020: Gli schermi nella pandemia, in Fata Morgana, 10 aprile 2020.

Craig, B., 2003: Interoception: the sense of the physiological condition of the body, in "Current Opinion in Neurobiology", 13, pp. 500-505.

Deleuze, G., 1981: Francis Bacon: The Logic of Sensation, transl. by D.W. Smith, Continuum, London : New York, 2003.

Derrida, J., 2000: On Touching - Jean-Luc Nancy, transl. By C. Irizarry, Stanford University Press Stanford, Stanford, 2005.

Didi-Huberman, G., 2008: La somiglianza per contatto: Archeologia, anacronismo e modernità dell'impronta, transl. by C. Tartarini, Bollati Boringhieri, Torino, 2018.

Eugeni, R., 2018: Temporalità sovrapposte. Articolazione del tempo e costruzione della presenza nei media immersivi, in A. Rabbito, La cultura visuale del XXI secolo. Cinema, teatro e new media, Meltemi, Milano 2018.

Gabbiadini, A., et al, 2020: Together Apart: The Mitigating Role of Digital Communication Technologies on Negative Affect During the COVID-19 Outbreak in Italy, "Front. Psychol., 21 October 2020.

Gallese, V., Guerra, M., 2015: Lo schermo empatico. Cinema e neuroscienze, Raffaello Cortina, Milano.

Ghilardi, M., 2011: Derrida e la questione dello sguardo, Aesthetica Preprint, Centro Internazionale Studi di Estetica, Palermo. 
Gibson, J.J. 1962: Observations on Active Touch, "Psychological Review", 69, (6), pp. 477-491.

Grunwald, M. et. al., 2008: Human Haptic Perception: Basics and Applications, Birkhauser, Basel.

Fellin, A., (eds), 1997: Tito Lucrezio Caro, De Rerum Natura, Utet, Novara, 2013.

Franzini, E., 2013: I sensi e l'arte, in P. D'Angelo, E. Franzini, G. Lombardo, S. Tedesco (eds), Costellazioni estetiche. Dalla storia alla neoestetica. Studi in onore di Luigi Russo, Edizioni Angelo Guerini, Milano, pp. 182-191.

Franzini, E., 2017: Un corpo da toccare. Riflessioni sulla tattilità da Burke a Herder, in Costazza A. (eds), Il romantico nel Classicisimo / il classico nel Romanticismo, LED, Milano, pp. 73-86.

Han, B.-C., 2012: The Transparency society, transl. by E. Butler, Stanford Briefs, Stanford, 2015.

Han, B.-C., 2013: In the Swarm. Digital Prospects, transl. by E. Butler, The MIT Press, Cambridge: London, 2017.

Han, B.-C., 2015: Saving Beauty, transl. by D. Steuer, Polity Press, Cambridge, 2018.

Herder, J.G., 1778: Sculpture. Some Observations on Shape and Form from Pygmalion's Creative Dream, transl. by et eds J. Gaiger, The University of Chicago Press, Chicago : London, 2002.

Malabou, C., 2020: To Quarantine from Quarantine: Rousseau, Robinson Crusoe, and "I", "Critical Inquiry", 23 March 2020.

Mazzocut-Mis, M., 2001: Estetica del tatto e della vista, in L. Russo (eds), La nuova estetica italiana, Aesthetica Preprint Supplementa, Centro Internazionale Studi di Estetica, Palermo, 9, pp. 137-144.

Mason, A.N. et al., 2021: Social media marketing gains importance after Covid-19, "Cogent Business \& Management", 8, 2021.

Mitchell, W.J.T. 2020: Present Tense: Time, Madness, and Democrazy, "Critical Inquiry".

Montani, P., 2014: Tecnologie della sensibilità. Estetica e immaginazione interattiva, Raffaello Cortina, Milano, 2014.

Montani, P., 2020: Emozioni dell'intelligenza. Un percorso nel sensorio digitale, Meltemi, Milano, 2020.

Most, G.W, 2005: Doubting Thomas, Harvard University Press, Cambridge : London.
Nancy, J.L., 2003: Alliterazioni, in Borgherini, M. (a cura di), Materia corpo. Anatomie, sconfinamenti, visioni, Quodlibet, Macerata, 2019, pp. 11-18.

Parisi, D., 2008: Fingerbombing,or 'Touching Is Good': The Cultural Construction of Technologized Touch, "The Senses \& Society 3", 3, pp. 302-27.

Parisi, D., 2018: Archaeologies of Touch: Interfacing with Haptics from Electricity to Computing, University of Minnesota Press, Minneapolis.

Paterson, M., 2007: The Senses of Touch: Haptics, Affects and Technologies, Berg, Oxford : New York.

Perniola, M., 1994: The sex appeal of the inorganic: philosophies of desire in the modern world, transl. by M. Verdicchio, Continuum, New York : London, 2004.

Petrelli, M., 2015: Tatto. Un senso intelligente tra processi percettivi ed esperienza estetica, "PiscoArt", 5, 2015, pp. 1-17.

Pinotti, A., 2001: Il corpo dello stile. Storia dell'arte come storia dell'estetica a partire da Semper, Riegl, Wölfflin, Mimesis, Milano.

Pinotti, A., 2007: The Touchable and the Untouchable. Merleau-Ponty and Bernard Berenson, "Phenomenology 2005. Selected Essays from Euro-Mediterranean Area Part 2”, v. 3, n. 2, pp. 479-498.

Pinotti, A., 2009: Guardare o toccare? Un'incertezza herderiana, "Aisthesis, Rivista on-line del Seminario Permanente di Estetica”, II, (1), pp. 177191.

Pinotti, A., (eds), 2018a: Costellazioni. Le parole di Walter Benjamin, Einaudi, Torino.

Pinotti, A., 2018b: Immagini che negano se stesse. Verso un' an-iconologia, in Montani, P., Cecchi, D., Feyles, M. (eds), Ambienti mediali, Meltemi, Milano, pp. 232-243.

Rabbito, A., 2020: Blade Runner 2049 e la relazione affettiva con le immagini tecnico-audiovisive, "Visual Cultural Studies. Rivista semestrale di cultura visuale", 1, 2020, pp. 223-248.

Rosen, J., 2020: During the Coronavirus Outbreak, the Urge to Touch One's Face Is Stronger Than Ever, "New Yorker", 11 Maggio 2020. 
Sarkady, D., et al., 2021: Virtual Reality as a Travel Substitution Tool During COVID-19, In: Wörndl W., Koo C., Stienmetz J.L. (eds.), "Information and Communication Technologies in Tourism", 2021, pp. 452-463.

Scialom, M., 2021: Predictive touch developed by Cambridge University/JLR team, "Cambridge Independent”, 21 September 2020.

Singh, R.V., et al 2020: Significant applications of virtual reality for COVID-19 pandemic, Diabetes \& Metabolic Syndrome: Clinical Research \& Reviews, v. 14, 4, pp. 661-664.

Strauven, W., 2018: Marinetti's Tattilismo Revisited Hand Travels, Tactile Screens, and Touch Cinema in the 21st Century, in R. Catanese (eds.), Futurist Cinema. Studies on Italian AvantGarde Film, Amsterdam University Press, pp. 69-87.

Žižek, S., 1997: The Plague of Fantasies, Verso, New York : London.

Žižek, S., 2020: Pandemic! Covid-19. Shakes the World, OR Books, New York : London. 